\title{
THE EUROPEAN COURT OF HUMAN RIGHTS' ENGAGEMENT WITH INTERNATIONAL HUMAN RIGHTS INSTRUMENTS: LOOKING AT THE CASES OF DOMESTIC VIOLENCE
}

\author{
EBRU DEMIR ${ }^{1}$
}

\begin{abstract}
In its recent jurisprudence on domestic violence, the European Court of Human Rights has started to examine domestic violence cases in the light of relevant international human rights law developed in this specific area. This article examines the engagement of the European Court of Human Rights with other international and regional human rights instruments in domestic violence cases. Upon examination, the article concludes that by integrating its case law into international human rights law the European Court of Human Rights broadens the scope of protection for domestic violence victims and maintains the coherence of international law.
\end{abstract}

Keywords: ECtHR; ECHR; domestic violence cases; international and regional human rights instruments; living instrument; fragmentation.

Summary: I. Introduction; II. Opuz V Turkey: Placing the Echr within International Human Rights Law; III. Engagement with Relevant International Law in Post-opuz Domestic Violence Cases: Gone Too FAR?; IV. CONCLUSION.

\section{INTRODUCTION}

The European Convention on Human Rights (the ECHR or the Convention), signed on 4 November 1950, is widely regarded as one of the most influential human rights treaties. For more than seven decades, the Convention has never ceased to be a significant instrument in international law. This is because the Convention as a "living instrument" (Dzehtsiarou, 2011; Mowbray, 2005; Theil, 2017) is interpreted by the European Court of Human Rights (the ECtHR or the Court) "in light of the present-day conditions" (Tyrer $v$ $U K$ para 31) and implemented in a dynamic and evolutive way.

To maintain the dynamism and effectiveness of the Convention, the ECtHR interprets it in the light of other international human rights documents and jurisprudence. The Court considers the Convention a living instrument and pays significant attention to common values and emerging consensus in international law while interpreting it (Letsas, 2013: 122). The Court places the ECHR within wider and ever-growing international human rights law in a way that maintains the coherence of international law (Rachovitsa, 2015: 873). This article, by engaging specifically with domestic violence cases before the ECtHR, shows how the Court's integrated approach provides stronger protection for

${ }^{1}$ Dr Lecturer, Ankara Yildirim Beyazit University Faculty of Law, Turkey (ebrudemir@ybu.edu.tr) ORCID: 0000-0003-2529-3383 
victims of domestic violence. The article argues that the ECtHR's effective use of the Convention can only be ensured by more integration of both international and regional human rights instruments in this area.

This article focuses on the ECtHR's jurisprudence on domestic violence and shows the ways in which the Court engages with other relevant international human rights instruments in its judgements. The second section will examine the landmark case of Opuz $v$ Turkey (2009). The ECtHR tackled domestic violence cases before Opuz v Turkey; ${ }^{2}$ however, this judgment differs from the previous decisions and creates a turning point in the ECtHR's jurisprudence. With Opuz v Turkey, the Court for the first time recognized violence against women as a systemic problem which amounts to a form of discrimination under the Convention. The passivity of the authorities in the case of Opuz v Turkey was connected, by the Court, to the wider negligence and even condoning of domestic violence on the part of the authorities in the country. Thus, the Court for the first time considered a breach of article 14 (prohibition of discrimination) in a domestic violence case. The section will illustrate the ways in which the ECtHR engaged with relevant international human rights law in this case.

The third section will focus on the domestic violence cases brought to the ECtHR after Opuz v Turkey. They will be called "post-Opuz cases" in this article. As in Opuz $v$ Turkey, the ECtHR interpreted the Convention in the light of the relevant human rights instruments in these cases as well. In post-Opuz cases the ECtHR, in addition to the Convention on the Elimination of All Forms of Discrimination Against Women (the CEDAW) of 1979, engaged with regional human rights treaties such as the Council of Europe Convention on Preventing and Combating Violence against Women and Domestic Violence (widely known as the Istanbul Convention) of 2011. The article will conclude that engagement with international and regional human rights instruments makes effective use of the Convention, provides stronger protection for victims of domestic violence, and maintains the coherence of international law.

\section{Opuz V Turkey: Placing the Echr within International Human Rights LaW}

Opuz v Turkey (2009) is a very typical domestic violence case which includes an escalation in violence against a woman and passivity on the part of the authorities. Nahide Opuz (the applicant) was a Turkish national who lived in Diyarbakır (a province in south-eastern Turkey). In 1995, Nahide Opuz married H.O., who was the son of her mother's then-husband, A.O. On 10 April 1995, both the applicant and her mother filed a complaint and reported that H.O. and A.O. had beaten them and threatened to kill them. The medical report stated that the injuries rendered both the applicant and her mother unfit to work for five days (Opuz v Turkey para 10). The public prosecutor filed indictments against H.O. and A.O. for the assaults and death threats. However, when the applicant and her mother withdrew their complaints, the public prosecutor decided not to pursue

\footnotetext{
${ }^{2}$ For instance, Bevacqua and $S$ v Bulgaria App no 71127/01 (ECtHR, 12 June 2008).
} 
the case. On 11 April 1996, H.O. beat the applicant and caused serious harm again. The medical report concluded that "the applicant's injuries were sufficient to endanger [the applicant's] life." (ibid para 13) The public prosecutor thereupon requested that H.O. be detained for questioning. The applicant was complainant at the hearing. However, H.O. was released by the court pending a trial since the applicant had recovered from the bodily harm caused by H.O. On 13 June 1996, the applicant withdrew her complaint, and the public prosecutor discontinued the case.

On the third reported assault against the applicant and her mother in February 1998, H.O. used a knife and caused serious injuries which rendered both the applicant and her mother unfit for work for three and five days respectively. On 6 March 1998, the public prosecutor found no evidence to prosecute H.O. and decided not to pursue the case since there had been no public interest in pursuing the case. On 4 March 1998 H.O. ran his car into the applicant and her mother. In his testimony, H.O. stated that the applicant and her mother had thrown themselves in front of the car. The applicant reported that her husband intended to kill them with his car. On 9 July 1998, however, the applicant and her mother changed their testimonies. They both confirmed H.O.'s testimony and withdrew their complaints. On 17 November 1998, the court decided that, even though the complaints were withdrawn, as a result of the severity of the injuries H.O. could be still convicted of the offence (ibid para 36). However, consequently the court imposed only a fine.

The violence against the applicant and her mother increasingly continued. On 29 October 2001, the applicant was hospitalised due to seven stab wounds. According to the hospital report, these wounds were not life-threatening. The public prosecutor imposed only a fine for the knife assault on the applicant. Although a month later the applicant filed a complaint alleging that her husband had been constantly threatening her, the public prosecutor found no evidence to prosecute the husband. After the incident on 29 October 2001, the applicant started living with her mother. Due to the life threats from H.O., the applicant and her mother decided to move to another city in Turkey (İzmir) in order to escape from H.O.'s violence. When H.O. found out about their escape plan, he shot the applicant's mother and killed her. In his testimony, H.O. stated that her mother-in-law was leading her wife to "an immoral life" and he killed her "for the sake of his honour and children." (ibid para 56) The domestic court considered that H.O. was provoked by the deceased and in addition, due to his good conduct during the hearings he was charged with 15 years and 10 months' imprisonment. Consequently, H.O. had been released pending the appeal proceedings and continued threatening the applicant with death. The applicant, thereupon, brought the case to the ECtHR as a last resort.

For the first time in a domestic violence case, the ECtHR concluded that, in conjunction with article 2 (right to life) and article 3 (freedom from torture, inhuman or degrading treatment or punishment), article 14 (prohibition of discrimination) had been violated by the state party. In its judgment, the Court stated:

"[b]earing in mind [...] the general and discriminatory judicial passivity in Turkey, albeit unintentional, mainly affected women, the Court considers that the violence suffered by the applicant and her mother may be regarded 
as gender-based violence which is a form of discrimination against women." (ibid para 200)

According to the Court, the overall unresponsiveness of the judicial system and impunity enjoyed by the perpetrators of domestic violence in a particular region of Turkey "indicated that there was insufficient commitment to take appropriate action to address domestic violence" (ibid). Opuz v Turkey importantly points out that the authorities' failure to act with due diligence to prevent the recurrence of violent attacks is genderbased discrimination and therefore amounts to discrimination on the basis of sex under article 14 of the ECHR (ibid para 169). The decision created "trickle-down effects" in Turkey. The recognition of the ineffectiveness of the legal and executive bodies by the ECtHR highlighted the need for structural change and in a way "forced" Turkey to adopt a new law on violence against women in March 2012 (Sönmez, 2020: 15).

With Opuz v Turkey, the ECtHR underlined the ineffectiveness of Turkey's criminal justice system in domestic violence cases. In this case, as an international human rights court, the ECtHR forced a state party's domestic criminal justice system to take an effective action (Erbas, 2020: 222). As Françoise Tulkens pointed out, the ECtHR often uses "criminal law to reinforce and safeguard more effectively the rights of victims of infringements of fundamental rights." (Tulkens, 2011: 584) In Opuz v Turkey, in order to protect the applicant's fundamental rights and freedoms, the Court regarded an efficient criminal justice system as essential. The close relationship between human rights law and criminal law became prominent in Opuz v Turkey (see Erbas, 2021).

Opuz v Turkey was a case in which the ECtHR successfully identified the power dynamics between victims and perpetrators of domestic violence. It is widely known that domestic violence victims drop charges "when the legal process fails to assure them that the decision to prosecute is safer than staying in the violent relationship." (Corsilles, 1994: 872-873) In other words, when sufficient protection is not provided, the victims are afraid of retaliation and often decide to withdraw their complaints and/or to stay in violent and abusive relationships. In Opuz v Turkey, the applicant and her mother dropped charges and withdrew their complaints a number of times (Opuz v Turkey para 18). Turkey claimed that each time the authorities commenced criminal proceedings, the applicant and her mother decided to terminate the proceedings, and this inhibited any interference by the authorities (ibid para 137). Importantly, the Court dismissed these claims and held that the authorities "have given exclusive weight to the need to refrain from interfering in what they perceived to be a 'family matter'..." and have failed to pay sufficient attention to the motives behind the withdrawal of the complaints (ibid para 143). The ECtHR's approach to the withdrawal of charges in domestic violence cases "provide[s] a useful blueprint for evaluating the reasonableness of State intervention" when the domestic violence victims decline to pursue the proceedings (Goldscheid and Liebowitz, 2015: 339).

In Opuz v Turkey, for the first time, the Court determined a state party's obligations when investigating domestic violence cases and highlighted the fact that gender stereotypes might seriously hamper women's access to justice (Murphy, 2019: 1351). The judgment declared that the attitude of those in charge resulted in or exacerbated the violence endured 
by the applicant and her mother (Bessant, 2015: 106). The state party's negligence and eventually failure to protect the applicant and her mother was considered to be highly related to the stereotypes and prejudice against women in Turkey (Fredman, 2019: 132). The state party's discriminatory attitude was identified and article 14 was interpreted "as entailing an obligation to protect." (Arnardóttir, 2017: 152)

Opuz v Turkey made it clear that treating a case of domestic violence as a private matter is no longer an option for the states parties to the ECHR (Bessant, 2015: 110). With this decision, the Court recognized that domestic violence is a systemic problem which goes beyond the individual cases at hand and reflects a fundamental imbalance of power and culture of impunity (Abdel-Monem, 2009: 32). The case builds on the Court's recent jurisprudence in which the Court increasingly adopts a "vulnerable groups" approach under article 14. ${ }^{3}$ (Arnardóttir, 2014; Peroni and Timmer, 2013) With Opuz v Turkey, this approach was used by the Court for the first time in order to protect women in southeastern Turkey as a vulnerable group. Such an innovative interpretation of article 14 in relation to gender-based violence was made possible by engaging extensively with the relevant international human rights instruments on the issue, in particular the CEDAW.

The Court held that when considering the definition and scope of discrimination against women, it has to take into account the definitions provided by specialised international human rights instruments on the issue of violence against women (Opuz v Turkey para 185). In its judgment, the ECtHR relied heavily on the CEDAW especially when defining "discrimination against women" and underlining the obligations of the states parties under the CEDAW. The CEDAW in article 1 defines "discrimination against women" as:

"any distinction, exclusion or restriction made on the basis of sex which has the effect or purpose of impairing or nullifying the recognition, enjoyment or exercise by women, irrespective of their marital status, on a basis of equality of men and women, of human rights and fundamental freedoms in the political, economic, social, cultural, civil or any other field." (Convention on the Elimination of All Forms of Discrimination Against Women art 1)

The CEDAW in article 2 obliges the states parties to "condemn discrimination against women in all its forms" (ibid art 2) and "to take all appropriate measures to eliminate discrimination against women by any person, organization or enterprise.” (ibid art 2.e.) As Carmelo Danisi pointed out, even though the ECtHR had found violations of article 2 and article 3 of the ECHR, it is clear that the Court "deemed it appropriate to investigate the events denounced by Mrs Opuz under article 14 [too]" (Danisi, 2011: 800). Thus, it was a deliberate choice to engage with the relevant international law on violence

\footnotetext{
${ }^{3}$ Oddny Mjoll Arnardóttir points out that in the Court's jurisprudence: “... while the vulnerable groups approach is not always mentioned, or is mentioned without elaboration of the relational understanding informing it, the awareness of social context and vulnerability implied may still inform the judgment." (Arnardóttir, 2017: 170)
} 
against women and to integrate the ECtHR case law into the wider international human rights law on this issue.

Since the Golder $v$ UK judgment, ${ }^{4}$ in various decisions ${ }^{5}$ the ECtHR has interpreted the ECHR in compliance with the Vienna Convention of 23 May 1969 on the Law of Treaties (the Vienna Convention). In order to determine the meanings of specific terms and phrases (such as gender-based violence and discrimination against women), the Court noted that it is guided mainly by the rules of interpretation provided in the Vienna Convention (Demir and Baykara v Turkey para 65). The Vienna Convention in article 31.3.c. declares that any relevant rules of international law applicable in the relations between the parties should be taken into account in the interpretation of treaties. By relying on this article, the ECtHR maintains an evolutive treaty interpretation method and expands the scope of the rights guaranteed under the ECHR in the light of relevant sources of international law (Arato, 2012: 353). In the Opuz v Turkey case, the Court engaged with the CEDAW's definition of "gender-based discrimination" and therefore interpreted the ECHR in its "normative environment" (Blaker Strand, 2020).

In addition to the CEDAW, the ECtHR considered the CEDAW Committee's General Recommendation No. 19 (1992) as relevant international law in its ruling in Opuz $v$ Turkey. General Recommendation No. 19 is a turning point in international human rights law and demonstrates a new level of depth of analysis on the issue of violence against women (Vijeyarasa, 2020: 157). It focuses specifically on violence against women and is considered to be one of the most important general recommendations of the CEDAW Committee since it points out that discrimination against women and violence against women are closely connected (Šimonović, 2014: 601).

Differently from the ECtHR, the CEDAW and its committee pay significant attention to the underlying causes of violence against women. The Court's engagement with the General Recommendation No. 19 in Opuz v Turkey therefore enabled the Court to conclude that violence against the applicant and her mother is a reflection of systemic discrimination against women in Turkey. The state authorities' passivity towards domestic violence cases was considered in connection with the general attitude towards women. In its ruling, the Court quotes articles 2(f), 5 and 10 (c) of the General Recommendation No. 19, which states that:

"11. Traditional attitudes by which women are regarded as subordinate to men or as having stereotyped roles perpetuate widespread practices

\footnotetext{
${ }^{4}$ According to George Letsas: “... the use of the VCLT [Vienna Convention on the Law of Treaties] in Golder inaguarated the Court's rejection of originalism (in both the textualist and the intentionalist strands) and paved the way for the development of the doctrines of autonomous concepts and evolutive interpretation." (Letsas, 2010: 520)

${ }^{5}$ See for instance Golder v UK App no 4451/70 (ECtHR, 21 February 1975) paras 29 and 35; Johnston and others $v$ Ireland App no 9697/82 (ECtHR, 18 December 1986) para 51; Fogarty v UK App no 37112/97 (ECtHR, 21 November 2001) para 35; Al-Adsani v UK App no 35763/97 (ECtHR, 21 November 2001) para 55; Neulinger and Shuruk $v$ Switzerland App no 41615/07 (ECtHR, 6 July 2010) para 131.
} 
involving violence or coercion, such as family violence and abuse, forced marriage, dowry deaths, acid attacks and female circumcision. Such prejudices and practices may justify gender-based violence as a form of protection or control of women. The effect of such violence on the physical and mental integrity of women is to deprive them of the equal enjoyment, exercise and knowledge of human rights and fundamental freedoms. While this comment addresses mainly actual or threatened violence the underlying consequences of these forms of gender-based violence help to maintain women in subordinate roles and contribute to the low level political participation and to their lower level of education, skills and work opportunities." (UN Committee on the Elimination of Discrimination Against Women, CEDAW General Recommendation No. 19: Violence against Women, 1992: articles 2.f., 5 and 10.c.)

By the Court, the authorities' negligence was considered related to the gendered hierarchies and stereotypes expressed in the General Recommendation No. 19. As Sandra Fredman remarked, condoning domestic violence on the grounds that it happens within the domestic sphere reflects a deep-seated negation of women as persons (Fredman, 2016: 292). Since the gendered hierarchies and stereotypes were considered to be embedded within the legal bodies, the Court, by "[t]aking into account the ineffectiveness of domestic remedies in providing equal protection of law to the applicant and her mother in the enjoyment of their rights", held that the applicant was not obliged to exhaust domestic remedies to bring the case to the ECtHR (Opuz v Turkey para 201). By engaging with the relevant international law on the issue, the Court was able to observe that such condoning by the authorities is a reflection of discrimination against women and considerably undermines women's ability to enjoy their fundamental rights and freedoms through the domestic legal bodies.

In paragraphs 76 and 77 in the case of Opuz v Turkey, the ECtHR engaged with two cases before the CEDAW Committee on domestic violence. One of these cases was A.T. v Hungary (2005). In this case, the applicant stated that she was subjected to severe domestic violence and death threats by her husband (A.T. v Hungary para 2.1.). However, the applicant was not able to seek shelter since Hungary was not equipped to shelter the applicant and her disabled child (ibid). Also, there were no protection or restraining orders under Hungarian law at the time (ibid). The CEDAW Committee concluded that "legal and institutional arrangements in the state party are not yet ready to ensure the internationally expected, coordinated, comprehensive and effective protection and support for the victims of domestic violence." (ibid para 9.3.) The Committee requested Hungary to provide women fleeing domestic abuse with "the maximum protection of the law by acting with due diligence to prevent and respond to such violence against women" (ibid para 9.6.b).

The other case on domestic violence which guided the ECtHR in Opuzv Turkey was Fatma Yildirim v Austria (2007). In this case, Fatma Yildirim was constantly threatened with death and then killed by her husband (Fatma Yildirim v Austria para 2.13.). The CEDAW Committee held that the Austrian authorities knew or should have known how the 
situation was extremely dangerous for Fatma Yildirim (ibid para 12.1.4.). The Committee considered that Austria failed to detain the husband in order to protect Fatma Yildirim from death threats and severe forms of harassment and therefore did not act with due diligence (ibid paras 12.1.2. and 12.1.5.). In the case, Austria argued that an arrest warrant would be a "disproportionately invasive" measure which would result in an intervention in the domestic sphere (ibid para 12.1.5). However, the Committee concluded that "the perpetrator's rights cannot supersede women's human rights to life and to physical and mental integrity." (ibid)

Similarly, in Opuz v Turkey, Turkey maintained that the authorities could not convict the husband because such an intervention would amount to a breach of the applicant's and her husband's rights under article 8 of the ECHR (the right to respect for private and family life). By making references to the case of Fatma Yildirim $v$ Austria, the ECtHR dismissed Turkey's argument and underlined the states parties' positive obligations "to take preventive operational measures to protect individual whose life is at risk" (Opuz v Turkey paras 147-148) and "to strike a balance between a victim's Article 2, Article 3 or Article 8 rights in deciding on a course of action." (ibid para 138)

The ECtHR's engagement with relevant international law and international bodies' jurisprudence enabled the Court to adopt a more proactive role in the fight against gender-based violence and any kind of discrimination against women (Cartabia, 2011: 808). Vibeke Blaker Strand suggests that as a result of extensive engagement with other international human rights law instruments and jurisprudence, Opuz v Turkey became an example of "interpretive thickening" on the issue of the states parties' obligations in relation to domestic violence (Blaker Strand, 2020: 984). Interpretive thickening, according to Blaker Strand, emerged as a consequence of interaction between the ECtHR case law, human rights law and developments on regional and international levels (ibid). The Court, through interpretive thickening, was able to recognize the systemic problems which went beyond the individual case at hand. As a result, it expanded the scope of legal issues which should be considered to be relevant in domestic violence cases (ibid) By integrating its case law into international human rights law, the Court provided more robust human rights protection with respect to gender-based discrimination and domestic violence (ibid).

\section{Engagement with Relevant International Law in Post-OPUZ Domestic Violence Cases: Gone Too Far?}

Opuz v Turkey is a landmark case in the ECtHR's jurisprudence. It represents a significant change in the Court's approach on gender-based discrimination (Londono, 2009: 658). The Court's integration of its case law into wider international law on the issue of domestic violence is novel and has a potential to diminish the fragmentation in international law (cf. Rachovitsa, 2017). Such an integration, therefore, provides a welcome step to maintain the coherence of international law. The case has also led the way to an increase in domestic violence cases brought under article 14 and created a spillover effect on the ECtHR's case law in relation to domestic violence. Opuz v Turkey was 
followed by various domestic violence cases and importantly the ECtHR effectively used the article 14 in those cases too. ${ }^{6}$

In post-Opuz cases, the ECtHR continued engaging with the CEDAW and the CEDAW Committee's general recommendations. The case of Eremia and others $v$ Moldova (2013) was brought before the Court right after Opuz v Turkey. In reaching its conclusion, the Court extensively benefited from the report of the United Nations Special Rapporteur on violence against women in order to illustrate the patriarchal and discriminatory attitudes against women in Moldova (ibid para 37). The report points out that domestic violence is a major problem in Moldova, and it is "linked to women's overall subordinate position in society." (ibid) The statistics and the observations in the Special Rapporteur's report enabled the ECtHR to consider domestic violence a systemic problem which amounts to a form of discrimination under article 14 of the Convention.

Differently from Opuz v Turkey, it is interesting to note that in post-Opuz domestic violence cases, the ECtHR has increasingly integrated its case law within human rights developments on the regional level. In post-Opuz cases, the Court has engaged further with the recommendations of the Council of Europe's main bodies. In Eremia and others $v$ the Republic of Moldova, the Court considered the Recommendation Rec (2002) 5 of 30 April 2002 of the Committee of the Ministers of the Council of Europe as relevant international law in its ruling. According to this recommendation:

"33. (...) member States should introduce, develop and/or improve where necessary national policies against violence based on maximum safety and protection of victims, support and assistance, adjustment of the criminal and civil law, raising of public awareness, training for professionals confronted with violence against women and prevention.

34. The Committee of Ministers recommended, in particular, that member States should penalise serious violence against women such as sexual violence and rape, abuse of the vulnerability of pregnant, defenceless, ill, disabled or dependent victims, as well as penalising abuse of position by the perpetrators. The recommendation also stated that member States should ensure that all victims of violence are able to institute proceedings, make provisions to ensure that criminal proceedings can be initiated by the public prosecutor, encourage prosecutors to regard violence against women

\footnotetext{
${ }^{6}$ Eremia and others $v$ the Republic of Moldova App no 3564/11 (ECtHR, 28 May 2013); Mudric $v$ the Republic of Moldova App no 74839/10 (ECtHR, 16 July 2013); Valiuliene v Lithuania App no 33234/07 (ECtHR, 26 June 2013); T.M. and C. M. v the Republic of Moldova App no 26608/11 (ECtHR, 28 April 2014); Rumor v Italy App no 72964/10 (ECtHR, 27 May 2014); M.G. v Turkey App no 646/10 (ECtHR, 22 March 2016); Halime Kilic v Turkey App no 63034/11 (ECtHR, 28 June 2016); Talpis v Italy App no 41237/14 (ECtHR, 2 March 2017); Balsan v Romania App no 49645/09 (ECtHR, 23 May 2017); Volodina v Russia App no 41261/17 (ECtHR, 4 November 2019); J.D. and A v United Kingdom App nos 32949/17 and 34614/17 (ECtHR, 24 February 2020); Munteanu v the Republic of Moldova App no 34168/11 (ECtHR, 26 August 2020).
} 
as an aggravating or decisive factor in deciding whether or not to prosecute in the public interest, ensure where necessary that measures are taken to protect victims effectively against threats and possible acts of revenge and take specific measures to ensure that children's rights are protected during proceedings.

35. With regard to violence within the family, the Committee of Ministers recommended that Member states should classify all forms of violence within the family as criminal offences and envisage the possibility of taking measures in order, inter alia, to enable the judiciary to adopt interim measures aimed at protecting victims, to ban the perpetrator from contacting, communicating with or approaching the victim, or residing in or entering defined areas, to penalise all breaches of the measures imposed on the perpetrator and to establish a compulsory protocol for operation by the police, medical and social services." (ibid para 33)

In the following cases on domestic violence, such as Mudric $v$ the Republic of Moldova (2013), the Court noted that it is mainly guided by the domestic and relevant international materials summarised in the cases of Opuz v Turkey and Eremia and others $v$ the Republic of Moldova in its judgment (Mudric v the Republic of Moldova paras 2628). It can therefore be argued that Opuz v Turkey was the seminal case where the Court engaged with relevant international law (such as the CEDAW) whereas Eremia and others $v$ the Republic of Moldova was the landmark case where the Court engaged mainly with the regional human rights law and developments (such as the Council of Europe's human rights instruments). From this point of view, in post-Opuz cases it can be observed that the ECtHR increasingly engages with the case of Eremia and others $v$ the Republic of Moldova i.e. with the regional human rights instruments. In T.M. and C. M. v the Republic of Moldova (2014), for instance, the Court made a reference to the case of Eremia and others $v$ the Republic of Moldova and engaged only with the relevant regional human rights instruments (T.M. and C. M. v the Republic of Moldova para 25).

Whereas the Court's engagement with the relevant international and regional human rights instruments is a welcome step towards the protection of domestic violence victims, the Court's increasing use of non-binding instruments in its rulings have resulted in criticisms in the scholarship (Dzehtsiarou, 2018; Rachovitsa, 2015). The criticisms were raised after the case of Valiuliene $v$ Lithuania (2013). In this case, a Lithuanian national, Loreta Valiuliene complained that "criminal proceedings she had instituted had been futile" (Valiuliene v Lithuania para 3). The applicant stated that her live-in partner had beaten her up on multiple occasions. When the applicant informed the police about the violence in 2002, the police considered that there was insufficient evidence to prove that the applicant's partner was responsible for the bruises that the applicant had (ibid para 18). In 2003, the police investigator once again decided to discontinue the pre-trial investigation since there was not enough evidence that the applicant was beaten by her partner (ibid para 19). When the case was brought before the ECtHR, the Court held that there had been a violation of article 3 of the Convention (freedom from torture, inhuman or degrading treatment or punishment). 
In this case, the ECtHR interestingly made no reference to its earlier jurisprudence on domestic violence. First of all, the Court engaged with the CEDAW which was ratified by Lithuania in 1994. The treaty was legally binding for the state party when Loreta Valiuliene was objected to violence and therefore the ECtHR's consideration of this treaty as relevant international law did not constitute a problem. The Court pointed out that the CEDAW Committee issued concluding observations on the state in 2004 and underlined the high prevalence of violence against women in the country, in particular domestic violence (ibid para 39). The CEDAW Committee reported that it was concerned that domestic violence was considered a private matter by police, health officers and the relevant authorities and society at large in Lithuania (ibid para 39). The Court later engaged with the United Nations Secretary General's report which presented statistics and proved the prevalence of domestic violence in the country at stake (ibid para 40). Both the CEDAW Committee's concluding observations and the United Nations Secretary General's report indicated the ineffectiveness of domestic remedies in providing equal protection of law to domestic violence victims in Lithuania.

What makes this case interesting and legally open-to-debate is that the ECtHR in its ruling considered a treaty to which Lithuania is not a party as relevant international law: the Convention on Preventing and Combating Violence against Women and Domestic Violence of 2011 (widely known as the Istanbul Convention). The Court stated that:

"The Convention has been signed by twenty eight Council of Europe Member States and ratified by three. The Convention has not yet entered into force, nor has it been signed by Lithuania. One of the purposes of the Convention is to protect women against all forms of violence, and prevent, prosecute and eliminate violence against women and domestic violence.' (ibid para 41)

It is important that the ECtHR considered the Istanbul Convention as relevant since it "contains very detailed provisions on the responses which states should adopt regarding the issue of domestic violence." (McQuigg, 2014: 769) The case also shows that, similar to Eremia and others $v$ the Republic of Moldova, the ECtHR is determined to continue engaging with regional human rights instruments. The Court's approach seems to be consistent because it continued considering the Istanbul Convention as relevant international law in very recent cases on domestic violence (such as Halime Kilic $v$ Turkey para 64; J.D. and A v United Kingdom paras 50 and 51; Talpis v Italy para 58; Volodina $v$ Russia para 60). Besides, the Court's engagement with the Istanbul Convention also created a motivation for non-member states to sign this international human rights document. For instance, Lithuania signed the Istanbul Convention three months after the issuing of the case of Valiuliene $v$ Lithuania. $^{7}$ Therefore, Valiuliene $v$ Lithuania once again proves that the ECtHR, with its recent jurisprudence, has become a key actor for the protection of domestic violence victims.

\footnotetext{
${ }^{7}$ The case was first issued on 26 March 2013 and Lithuania signed the Convention on Preventing and Combating Violence against Women and Domestic Violence on 7 June 2013.
} 
An examination of the ECtHR's jurisprudence shows that the Court takes the view that "it should not exclude from its consideration non-binding materials (including declarations, guidelines, or reports) or relevant human rights treaties to which the respondent state is not a party." (Letsas, 2010: 521) Especially since 2000, the Court increasingly engages with non-binding (soft) law. ${ }^{8}$ The Court's engagement with relevant (binding and non-binding) human rights instruments are significant since such an engagement both creates robust human rights protection and also diminishes fragmentation in international law. Interestingly, this shows that in domestic violence cases the state parties' neglect of relevant non-binding human rights instruments or withdrawal from human rights treaties (for example, Turkey's withdrawal from the Istanbul Convention in July 2021) does not prevent the ECtHR from considering these instruments as relevant in its judgments.

Nevertheless, the Court's engagement with a convention which the state party at stake (Lithuania) did not sign and ratify created legal discussions in the scholarship. Adamantia Rachovitsa's research shows that, in its jurisprudence, the Court does not hesitate to employ non-binding law including, but not limited to, Council of Europe Parliamentary Assembly resolutions; the Universal Declaration on Human Rights; and reports by UN Special Rapporteurs (Rachovitsa, 2015: 880). In Rachovitsa's view, with this approach the Court does not draw a clear line between binding and non-binding (soft law) instruments and creates ambiguity regarding the precise obligations of the member states (ibid).

Rachovitsa, however, fails to give sufficient consideration to the ECtHR's living instrument doctrine, which makes the Court effective, dynamic, evolutive, and relevant in international law. For the Convention to be a living instrument, the Court has to be responsive to changing conditions and this is only possible when and if the Court integrates its case law within the broader international law. Indeed, the Court's jurisprudence employs various norms and principles "emanating from other special regimes such as those governing child rights, torture, armed conflict, refugee rights and civil and political rights, particularly these provide more specific guidance than the ECHR." (McInerneyLankford, 2012: 615) The Court points out that "the principles underlying the Convention cannot be interpreted and applied in a vacuum" (Bankovic and others $v$ Belgium and 16 Other States para 57) and it "should be interpreted in harmony with other rules of international law of which it forms part (...)." (Al-Adsani v UK para 55) The Court itself states in another case that:

"The Court, in defining the meaning of terms and notions in the text of the Convention, can and must take into account elements of international

\footnotetext{
${ }^{8}$ Including but not limited to Christine Goodwin v UK App no 28957/95 (ECtHR, 11 July 2002); Oneryildiz $v$ Turkey App no 48939/99 (ECtHR, 30 November 2004); Glass v UK App no 61827/00 (ECtHR, 9 March 2004); Taskin and others v Turkey App no 46117/99 (ECtHR, 30 March 2005); Bekos and Koutropoulos v Greece App no 15250/02 (ECtHR, 13 December 2005); Siliadin v France App no 73316/01 (ECtHR, 26 October 2005); Russian Conservative Party of Entrepreneurs and others v Russia App nos 55066/00 and 55638/00 (ECtHR, 11 April 2007).
} 
law other than the Convention, the interpretation of such elements by competent organs, and the practice of European States reflecting their common values. (...)

$\ldots$ it is not necessary for the respondent State to have ratified the entire collection of instruments that are applicable in respect of the precise subject matter or the case concerned. It will be sufficient for the Court that the relevant international instruments denote a continuous evolution in the norms and principles applied in international law or in the domestic law of the majority of member States of the Council of Europe and show, in a precise area, that there is common ground in modern societies..." (Demir and Baykara $v$ Turkey paras 85 and 86).

As seen, the Court considers international law as a whole and does not require the states parties' signature in order to integrate the developing norms and principles into its case law. The cross-fertilization among international human rights instruments in the ECtHR's jurisprudence gives evidence to the full support given by the Court to the relevance of systemic integration (Pitea, 2013: 557). The Court is keen to link its own analyses and interpretations to wider trends of international human rights law (Viljanen, 2008: 250; Wildhaber, 2007). This is indeed what makes the ECHR "a living instrument". Irrespective of whether the states parties have agreed to be formally bound by relevant international law, the Court states that it is mainly concerned with developing the ECHR in light of trends in contemporary international human rights law (Arato, 2012: 385). Thus, Valiuliene $v$ Lithuania is neither the first nor the last case in which the Court engages with an international treaty not signed and ratified by the state party in dispute.

\section{Conclusion}

This article argues that by engaging its case law with the relevant international human rights instruments and jurisprudence, the ECtHR provides robust human rights protection for domestic violence victims. Starting with the case of Opuz $v$ Turkey, the ECtHR considered domestic violence as a breach of article 14 of the ECHR (prohibition of discrimination) for the first time. In this case, the Court directly connected the ineffectiveness of the domestic judicial and executive bodies to the systemic discrimination against women in south-eastern Turkey. The Court's innovative interpretation of article 14 in the case of domestic violence created a turning point in the Court's jurisprudence and a number of violation judgments in domestic violence cases followed Opuz v Turkey.

This article shows that, in Opuz and post-Opuz domestic violence cases, the Court has increasingly engaged with relevant international and regional human rights instruments without drawing a line between binding or non-binding human rights instruments. Whereas the Court's engagement with these instruments is a welcome step towards the protection of domestic violence victims, the Court's extensive use of soft law in its rulings has resulted in severe criticisms in the scholarship. As a response to these criticisms, this 
article argues that the Court's engagement with relevant (binding or non-binding) human rights instruments is significant, since such an engagement both creates robust human rights protection and also diminishes fragmentation in international law. According to the present author, the effective use of the Convention is only possible through the Court's greater engagement with wider international human rights law.

\section{BiBLIOGRAPHY}

Abdel-Monem T. (2009) Opuz v. Turkey: Europe's Landmark Judgment on Violence against Women. Human Rights Brief 17(1): 29-33.

Arato J. (2012) Constitutional Transformation in the ECtHR: Strasbourg's Expansive Recourse to External Rules of International Law. Brooklyn Journal of International Law 37(2): 349-387.

Arnardóttir O. M. (2014) The Differences that Make a Difference: Recent Developments on the Discrimination Grounds and the Margin of Appreciation under Article 14 of the European Convention on Human Rights. Human Rights Law Review 14: 647-670. https://doi.org/10.1093/hrlr/ngu025

Arnardóttir O. M. (2017) Vulnerability under Article 14 of the European Convention on Human Rights: Innovation or Business as Usual? Oslo Law Review 1(3): 150 171. https://doi.org/10.18261/issn.2387-3299-2017-03-03

Bessant C. (2015) Protecting Victims of Domestic Violence-Have We Got the Balance Right? The Journal of Criminal Law 79(2): 102-121. https://doi. org/10.1177/0022018315574820

Blaker Strand V. (2020) Interpreting the ECHR in its Normative Environment: Interaction between the ECHR, the UN Convention on the Elimination of all forms of Discrimination Against Women and the UN Convention on the Rights of the Child. The International Journal of Human Rights 24(7): 979-992. https://doi.org/10.108 0/13642987.2019.1574423

Cartabia M. (2011) The European Court of Human Rights: judging nondiscrimination. International Journal of Constitutional Law 9(3-4): 808-814. https://doi. org/10.1093/icon/mor043

Corsilles A. (1994) No-Drop Policies in the Prosecution of Domestic Violence Cases: Guarantee To Action or Dangerous Solution? Fordham Law Review 63: 853-881.

Council of Europe, European Convention for the Protection of Human Rights and Fundamental Freedoms, 4 November 1950.

Council of Europe, The Council of Europe Convention on Preventing and Combating Violence against Women and Domestic Violence, April 2011.

Council of Europe, The Committee of the Ministers of the Council of Europe, Recommendation Rec (2002) 5 of 30 April 2002. 
Danisi C. (2011) How far can the European Court of Human Rights Go in the Fight against Discrimination? Defining New Standards in its Nondiscrimination Jurisprudence. International Journal of Constitutional Law 9(3-4): 793-807. https://doi. org/10.1093/icon/mor044

Dzehtsiarou K. (2011) European Consensus and the Evolutive Interpretation of the European Convention on Human Rights. German Law Journal 12(10): 1730-1745. https://doi.org/10.1017/S2071832200017533

Dzehtsiarou K. (2018) What is Law for the European Court of Human Rights? Georgetown Journal of International Law 49:89-134.

Erbas R. (2020) Effective Criminal Investigations in Combating Domestic Violence and the ECtHR: Prima Ratio v. Ultima Ratio?. In: Elettra Stradella (ed.) Gender Based Approaches to the Law and Juris Dictio In Europe. Pisa University Press, pp.221240. https://doi.org/10.1016/j.wsif.2021.102468

Erbas R. (2021) Effective Criminal Investigations for Women Victims of Domestic Violence: The Approach of the ECtHR. Women's Studies International Forum 86: $1-12$.

Fredman S. (2016) Emerging from the Shadows: Substantive Equality and Article 14 of the European Convention on Human Rights. Human Rights Law Review 16(2): 273-301. https://doi.org/10.1093/hrlr/ngw001

Fredman S. (2019) Gender Equality and the European Convention on Human Rights. In: Reilly N (ed.) International Human Rights of Women. Springer, pp. 121-138. https://doi.org/10.1007/978-981-10-8905-3_9

Goldscheid J. and Liebowitz D. J. (2015) Due Diligence and Gender Violence: Parsing its Power and its Perils. Cornell International Law Journal 48: 301-345.

Letsas G. (2010) Strasbourg's Interpretive Ethic: Lessons for the International Lawyer. European Journal of International Law 21(3): 509-541. https://doi.org/10.1093/ ejil/chq056

Letsas G. (2013) The ECHR as a Living Instrument: Its Meaning and Legitimacy. In: Følledal A, Peters B, and Ulfstein G (eds) Constituting Europe: The European Court of Human Rights in a National, European and Global Context. Cambridge University Press, pp. 106-141. https://doi.org/10.1017/ CBO9781139169295.005

Londono P. (2009) Developing Human Rights Principles in Cases of Gender-based Violence: Opuz v Turkey in the European Court of Human Rights. Human Rights Law Review 9(4): 657-667. https://doi.org/10.1093/hrlr/ngp022

McInerney-Lankford S. (2012) Fragmentation of International Law Redux: The Case of Strasbourg. Oxford Journal of Legal Studies 32(3): 609-632. https://doi. org/10.1093/ojls/gqs014 
McQuigg R. J. A. (2014) The European Court of Human Rights and Domestic Violence: Valiuliene v. Lithuania. The International Journal of Human Rights 18(7-8): 756773. https://doi.org/10.1080/13642987.2014.930820

Mowbray A. (2005) The Creativity of the European Court of Human Rights. Human Rights Law Review 5(1): 57-79. https://doi.org/10.1093/hrlrev/ngi003

Murphy S. (2019) Domestic Violence as Sex Discrimination: Ten Years Since the Seminal European Court of Human Rights Decision in Opuz v. Turkey. International Law and Politics 51: 1347-1358.

Peroni L. and Timmer A. (2013) Vulnerable groups: The promise of an emerging concept in European Human Rights Convention law. International Journal of Constitutional Law 11(4): 1056-1085. https://doi.org/10.1093/icon/mot042

Pitea C. (2013) Interpreting the ECHR in the Light of 'Other' International Instruments: Systemic Integration or Fragmentation of Rules on Treaty Interpretation? In: Boschiero N, Scovazzi T, Pitea C, et al. (eds) International Courts and the Development of International Law: Essays in Honour of Tullio Treves. Springer, pp. 545-559. https://doi.org/10.1007/978-90-6704-894-1_40

Rachovitsa A. (2015) Fragmentation of International Law Revisited: Insights, Good Practices, and Lessons to be Learned from the Case Law of the European Court of Human Rights. Leiden Journal of International Law 28(4): 863-885. https://doi. org/10.1017/S092215651500045X

Rachovitsa A. (2017) The Principle of Systemic Integration in Human Rights Law. International and Comparative Law Quarterly 66(3): 557-588. https://doi. org/10.1017/S0020589317000185

Šimonović D. (2014) Global and Regional Standards on Violence Against Women: The Evolution and Synergy of the CEDAW and Istanbul Conventions. Human Rights Quarterly 36(3): 590-606. https://doi.org/10.1353/hrq.2014.0040

Sönmez E. Y. (2020) Avrupa İnsan Hakları Mahkemesi Kararları Işı̆̆ında Türkiye'de Kadına Yönelik Şiddetin Önlenmesi. İstanbul Üniversitesi Kadın Araştırmaları Dergisi 20: 1-17. https://doi.org/10.26650/iukad.2020.658992

Theil S. (2017) Is the 'Living Instrument' Approach of the European Court of Human Rights Compatible with the ECHR and International Law? Kluwer Law International 23: 587-614.

Tulkens F. (2011) The Paradoxical Relationship between Criminal Law and Human Rights Journal of International Criminal Justice 9:577-595. https://doi.org/10.1093/jicj/ mqr028

UN Committee on the Elimination of Discrimination Against Women (CEDAW), CEDAW General Recommendation No.19: Violence Against Women, 1992.

UN General Assembly, Convention on the Elimination of All Forms of Discrimination Against Women, 18 December 1979, United Nations Treaty Series, vol. 1249. 
Vijeyarasa R. (2020) CEDAW's General Recommendation No. 35: A Quarter of a Century of Evolutionary Approaches to Violence Against Women. Journal of Human Rights 19(2): 153-167. https://doi.org/10.1080/14754835.2019.1686347

Viljanen J. (2008) The Role of the European Court of Human Rights as a Developer of International Human Rights Law. Cuadernos Constitucionales de la Cátedra Fadrique Furió Ceriol 62-63: 249-265.

Wildhaber L. (2007) The European Convention on Human Rights and International Law. International and Comparative Law Quarterly 56: 217-231. https://doi. org/10.1093/iclq/lei163

\section{Cases}

Al-Adsani v UK App no 35763/97 (ECtHR, 21 November 2001). https://doi. org/10.5144/0256-4947.2001.258a

A.T. v Hungary Communication No 2/2003 (CEDAW, 26 January 2005).

Balsan v Romania App no 49645/09 (ECtHR, 23 May 2017).

Bankovic and others v Belgium and 16 Other States App no 52207/99 (ECtHR, 12 December 2001). https://doi.org/10.1163/157181301401748405

Bekos and Koutropoulos v Greece App no 15250/02 (ECtHR, 13 December 2005). https:// doi.org/10.1299/jsmeintmp.2005.13_2

Bevacqua and S v Bulgaria App no 71127/01 (ECtHR, 12 June 2008).

Christine Goodwin v UK App no 28957/95 (ECtHR, 11 July 2002).

Demir and Baykara v Turkey App no 34503/97 (ECtHR, 12 November 2008).

Eremia and others v the Republic of Moldova App no 3564/11 (ECtHR, 28 May 2013).

Fatma Yildirim v Austria Communication No 6/2005 (CEDAW, 1 October 2007).

Fogarty v UK App no 37112/97 (ECtHR, 21 November 2001).

Glass v UK App no 61827/00 (ECtHR, 9 March 2004).

Golder v UK App no 4451/70 (ECtHR, 21 February 1975).

Halime Kilic v Turkey App no 63034/11 (ECtHR, 28 June 2016).

J.D. and A v United Kingdom App nos 32949/17 and 34614/17 (ECtHR, 24 February 2020).

Johnston and others v Ireland App no 9697/82 (ECtHR, 18 December 1986).

M.G. v Turkey App no 646/10 (ECtHR, 22 March 2016).

Mudric v the Republic of Moldova App no 74839/10 (ECtHR, 16 July 2013).

Munteanu v the Republic of Moldova App no 34168/11 (ECtHR, 26 August 2020). 
Neulinger and Shuruk v Switzerland App no 41615/07 (ECtHR, 6 July 2010).

Oneryildiz v Turkey App no 48939/99 (ECtHR, 30 November 2004).

Opuz v Turkey App No 33401/02 (ECtHR, 9 June 2009).

Rumor v Italy App no 72964/10 (ECtHR, 27 May 2014). https://doi.org/10.4244/ EIJV10I1A6

Russian Conservative Party of Entrepreneurs and others v Russia App nos 55066/00 and 55638/00 (ECtHR, 11 April 2007).

Siliadin v France App no 73316/01 (ECtHR, 26 October 2005).

T.M. and C. M. v the Republic of Moldova App no 26608/11 (ECtHR, 28 April 2014).

Talpis v Italy App no 41237/14 (ECtHR, 2 March 2017).

Taskin and others v Turkey App no 46117/99 (ECtHR, 30 March 2005).

Tyrer v UK App no 5856/72 (ECtHR, 25 April 1978).

Valiuliene v Lithuania App no 33234/07 (ECtHR, 26 June 2013).

Volodina v Russia App no 41261/17 (ECtHR, 4 November 2019).

Received: May $12^{\text {th }} 2021$

Accepted: July $21^{\text {st }} 2021$ 